Studia Judaica 24 (2021), nr 2 (48), s. 313-341

doi:10.4467/24500100STJ.21.014.15069

Agata Jaworska (iD https://orcid.org/0000-0001-7369-9957

\title{
Obraz kobiety wykorzenionej w prozie nowohebrajskiej na przykładzie opowiadań Icchaka Dowa Berkowicza
}

\author{
THE IMAGE OF AN UPROOTED WOMAN IN NEW HEBREW PROSE \\ ON THE BASIS OF SHORT STORIES BY ISAAC DOV BERKOWITZ
}

\begin{abstract}
The uprooted hero is one of the leading themes in Hebrew prose at the turn of the nineteenth and twentieth centuries. It also occupies a central place in the stories of Isaac Dov Berkowitz. The uproot metaphor reflects the hero's alienation in many aspects of life. In a broader sense, it is a reaction to the sense of suspension between the traditions of their ancestors and the progressive secularization of their world. The exceptions are stories whose protagonist is an uprooted female figure. This is a unique phenomenon considering the lower hierarchical position of women in Judaism and the limited access to religious and secular literature at the time. The female uprooting results from other factors. Women do not follow science or ideology, they want to free themselves from the norms of Jewish customs, escape loneliness and experience individualism. The objective of the paper is to present the image of Berkowitz's heroines and compare them from the perspective of alienation. The starting point for consideration is the classification of the uprooted and the division of Berkowitz's heroes according to Nurit Govrin and variants of the uprooting by Simon Halkin.
\end{abstract}

Keywords: uprooted woman, Berkowitz, Diaspora, Hebrew prose, talush.

Słowa kluczowe: kobieta wykorzeniona, Berkowicz, diaspora, proza nowohebrajska, talusz. 


\section{Bohater „wykorzeniony” w literaturze nowohebrajskiej}

Bohater wykorzeniony i jego specyfika należą do najważniejszych motywów prozy nowohebrajskiej przełomu XIX i XX w. W języku hebrajskim postać ta nazywana jest talusz, co znaczy 'człowiek oderwany od korzeni' ${ }^{1}$. Określenie to po raz pierwszy pojawiło się w 1904 r. jako tytuł jednego z utworów Icchaka Dowa Berkowicza ${ }^{2}$. Najtrafniej odzwierciedla ono, z jednej strony, wyzwolenie się z krępujących więzów tradycji, dążenie do niezależności - tak osobistej, jak intelektualnej - i samorozwój. Z drugiej zaś strony wyraża brak solidnego fundamentu życiowego i poczucia bezpieczeństwa. W szerszym kontekście talusz jest symbolem upadku europejskiego sztetla, a także społeczno-ekonomicznych ograniczeń, których doświadczali Żydzi Europy Wschodniej ${ }^{3}$. „Wykorzeniony” jest też protagonistą licznych opowiadań Michy Josefa Berdyczewskiego, Uriego Nissana Gnessina czy Gerszona Szofmana. Najczęściej jest w nich ukazany jako dojrzały mężczyzna, inteligent, idealista oddalający się od żydowskiej obyczajowości i religii zarówno w dosłownym, jak i metaforycznym sensie. Dystans ten widoczny jest na poszczególnych etapach życia bohatera - od rozważenia decyzji o opuszczeniu sztetla, przez przeprowadzkę do miasta, po powrót do domu i nieumiejętność ponownego przystosowania się do panujących w nim reguł.

Celem artykułu jest ukazanie obrazu wykorzenionych postaci kobiecych występujących w prozie Berkowicza. Został on oparty na analizie nieprzetłumaczonych dotąd na język polski utworów Melafefonim [Ogórki] oraz

${ }^{1}$ Oxford English-Hebrew and Hebrew-English Dictionary, red. Ya'acov Levy, Jerusalem 1995, s. 306; Nurit Gowrin, Tliszut we-hitchadszut: Ha-siporet ha-iwrit bereszit ha-mea ha-esrim ba-gola u-we-Erec-Israel, Tel Awiw 1985, s. 17-26.

${ }^{2}$ Urodził się 16 października 1885 r. w Słucku na terenie obecnej Białorusi (wówczas Cesarstwo Rosyjskie), zmarł 29 marca 1967 r. w Tel Awiwie. Był żydowskim prozaikiem tworzącym w językach hebrajskim i jidysz, tłumaczem i dramaturgiem. W 1903 r. dzięki opowiadaniu Moszkele-Chazir wygrał pierwszy w historii współczesnej literatury hebrajskiej konkurs literacki zorganizowany przez czasopismo „Ha-Cofe”. Pracował jako redaktor czasopism, m.in. „Ha-Zman”, „Ha-Olam”, „Ha-Toren”, „Ha-Miklat” i „Moznajim”. Był głównym i przez wiele lat jedynym tłumaczem na hebrajski dzieł swojego teścia Szolema Alejchema. Zanim w 1928 r. ostatecznie osiadł w Izraelu, pomieszkiwał w różnych częściach Europy, a także w Stanach Zjednoczonych. W 1958 r. został laureatem Nagrody Izraela w dziedzinie literatury. Avraham Holtz, Isaac Dov Berkowitz: Voice of the Uprooted, London 1973, s. 15-27; Icchak D. Berkowicz, Sipurim, Kraków 1910 [dalej: Sipurim], s. 1-19.

${ }^{3}$ Problemy Żydów w strefie osiedlenia wynikały m.in. z przeludnienia, ograniczeń społeczno-ekonomicznych, z postępujących procesów pauperyzacji i industrializacji, przymusu przebranżowienia się. Należy też wspomnieć o nasilających się ówcześnie nastrojach antysemickich nierzadko skutkujących pogromami. Szimon Halkin, Modern Hebrew Literature. From the Enlightenment to the Birth of the State of Israel: Trends and Values, New York 1970, s. 15-33; Gowrin, Tliszut..., s. 21-22. 
Karet [Wygnanie] $]^{4}$ Zarówno twórczość pisarza, jak i pojęcie tlusza (wykorzeniona) nie zostały omówione na gruncie polskim. Wybór opowiadań był celowy - losy kobiet przedstawiają ten sam problem widziany z odmiennej perspektywy. Należy podkreślić, iż bohaterki wspomnianych opowiadań powinno się postrzegać w kategorii kolejnego wariantu wykorzenionych, jednak nie jako żeńskie odpowiedniki taluszy, lecz jako osobne zjawisko. Przyczyny wykorzenienia u przedstawicieli obojga płci nie były tożsame. Wśród większości mężczyzn wynikały z chęci zdobycia wykształcenia lub podążania za określoną ideologią, np. syjonizmem.

Mimo złożoności i specyfiki postaci talusza - jak to zwykle bywa w przypadku toposów - możemy wyodrębnić jej uniwersalny, modelowy typ ${ }^{5}$. Ta topiczna „półgotowość formy”, jak ją określiła Janina Abramowska, jest dla toposu sytuacją typową, a nie wyjątkową. I choć możemy wyodrębnić pewne warianty tej postaci, to uniwersalne w tym wypadku wydaje się odcięcie korzeni. Motyw ten jest nie tylko powszechny, ale i ponadczasowy:

Jedną z cech toposu jest jego wariantowość. Czasem wymiana jednego członu pociąga za sobą wymianę drugiego [...]. Trwała jest tylko struktura semantyczno-logiczna, wyznaczająca precyzyjnie „zakres zmienności”. Jak widać, również w aspekcie przedstawieniowym topos stanowi konstrukcję półgotową. [...] Zależnie od potrzeby topos może być eliptycznie skrócony albo rozbudowany, często bywa redundantnie zwielokrotniony przez postawienie obok siebie kilku wariantów ${ }^{6}$.

Szimon Halkin podjął próbę wyodrębnienia trzech najpowszechniejszych wariantów wykorzenienia ${ }^{7}$. Klasyfikację otwiera bohater wykorzeniony ze swojego społeczeństwa i klasy społecznej. Znamienne w tym przypadku są tzw. spóźniony powrót do domu (określenie Kurzweila) i próby ponownej aklimatyzacji ${ }^{8}$. Ci, którzy odważyli się na ten krok, spotykali się z krytyką, podejrzliwością i rezerwą ze strony otoczenia. Dyplom ukończenia studiów oraz zmianę statusu społecznego traktowano z dużą

${ }^{4}$ Berkowicz, Sipurim..., s. 161-180; tenże, Sipurim niwcharim, Tel Awiw 1966 [dalej: Sipurim niwcharim], s. 161-180. Wszystkie przytoczone cytaty są oparte na przekładzie autorki artykułu. Jest to pionierskie tłumaczenie na język polski.

5 Janina Abramowska, Topos i niektóre miejsca wspólne badań literackich, „Pamiętnik Literacki” 73 (1982), nr 1-2, s. 14.

${ }^{6}$ Tamże, s. 16-17.

7 Szimon Halkin, Mawo la-siporet ha-iwrit. Reszimot lefi harcaotaw szel Sz. Halkin, Jeruszalajim 1959, s. 339-348; Agata Jaworska, Na rozdrożu: Wizerunek bohatera wykorzenionego (talusz) na przyktadzie prozy J. Ch. Brennera oraz M. J. Berdyczewskiego. Część I: Josef Chaim Brenner, [w:] Języki i cywilizacje. Młodzi badacze na stulecie Orientalistyki w Krakowie, red. Karolina W. Olszowska, Joanna Świt, Marcin Gajec, Kraków 2020, s. 23-37.

${ }^{8}$ Baruch Kurzweil, Zikaron la-riszonim, „Katharsis” (2008), nr 10, s. 199. 
dozą nieufności. Bohater tkwi w sytuacji bez wyjścia, zawieszony niejako pomiędzy światem tradycji a nowoczesnością. Skutkuje to m.in. niemożnością zdefiniowania swojej tożsamości, poczuciem braku przynależności do określonego miejsca - np. Talusz [Wykorzeniony], Mi-Merchakim [Z daleka] Berkowicza9.

Przedstawicielem drugiego wariantu jest bohater wykorzeniony ze swojego naturalnego środowiska i pozbawiony możliwości ponownego zakorzenienia się w nowej społeczności. Większość taluszy opuszczała sztetl po to, aby studiować w dużych miastach na świeckich uczelniach ${ }^{10}$. Bywało, że z biegiem lat nauka przestawała dawać im satysfakcję i zaczynali odczuwać pustkę. Pomimo ciekawości świata i kosmopolitycznego doń podejścia nie potrafili się przystosować do warunków życia w mieście, postrzegali je jako obce i przytłaczające. Nierzadko żyli w nędzy. Mężczyzn tych dręczyła samotność, nie potrafili nawiązać relacji z innymi. Samych siebie uważali za słabych i nieatrakcyjnych fizycznie ${ }^{11}$. Ich związki z kobietami były nieudane nie tylko z powodu dysfunkcji seksualnych, na które cierpieli, ale i nieumiejętności pełnego zaangażowania się w relację. Siła charakteru i nierzadko wyzwolone, liberalne podejście do życia wykształconych dziewcząt często budziły w nich lęk. Niepowodzenie w relacjach damsko-męskich pogłębiały wyobcowanie i samotność bohaterów. Mimo tęsknoty i nostalgicznych wspomnień o przeszłości wielu z nich zostało pozbawionych prawa powrotu w rodzinne strony (np. Menachem Berdyczewskiego). Wyprowadzka z domu nierzadko wiązała się także z odejściem od wiary i obyczajów, co przekładało się na zerwanie więzi z rodziną. Takie osoby były wydziedziczane lub uznawano je za zmarłe ${ }^{12}$.

Trzeci wariant wykorzenienia dotyczy bohaterów oderwanych od rzeczywistości, np. wyrzutków społecznych, kalek, szaleńców i osób z marginesu. Odnosi się on do osób skoncentrowanych wyłącznie na swoim wewnętrznym świecie uczuć i myśli. Snują one fantazje i utopijne wizje o życiu uniemożliwiające im odnalezienie się w otaczającym je świecie,

${ }^{9}$ Halkin, Mawo ..., s. 344.

${ }^{10}$ Przedstawiani jako miłośnicy pisarstwa, tworzyli m.in. autobiografie, opisywali dzieje Żydów, badali język i literaturę hebrajską.

${ }^{11}$ Wyjątkiem są np. utwory Ecel Gnessina lub Be-ejn matara Berszadskiego, w których bohater jest silny, pociągający i odważny, pragną go kobiety. Niemniej, oni także nie potrafią zbudować silnej więzi z partnerkami. W późniejszych latach talusz był przedmiotem krytyki palestyńskich pionierów, gdyż nie przystawał do stereotypowej wizji męskości wykreowanej przez syjonistycznych myślicieli. George L. Mosse, Nationalism and Sexuality: Respectability and Abnormal Sexuality in Modern Europe, New York 1985, s. 13-22.

${ }^{12}$ Halkin, Mawo..., s. 344-345. 
żyją poza czasem. Prześladują je natrętne myśli o śmierci mającej być dla nich wybawieniem od trudów codzienności. Los bohaterów jest z góry przegrany, pozostają na zawsze obcy, samotni i nieprzystający. Izolacja ta wychodzi poza społeczny i kulturowy kontekst - np. tytułowy „Obcy” w Ha-Zar Berdyczewskiego, Suli w Ba-Ganim [W ogrodach] Gnessina ${ }^{13}$.

Nurit Gowrin podzieliła taluszy na dwie grupy: diasporycznych (galutowych) oraz palestyńskich z tzw. jiszuwu. Klasyczni wykorzenieni reprezentujący diasporę to przede wszystkim bohaterowie kreowani przez Berdyczewskiego, Berkowicza i Szofmana. W większości przypadków są nimi młodzi, poszukujący sensu życia mężczyźni, którzy opuszczają sztetl i tułają się po europejskich stolicach, realizując marzenia o podłożu ideowym bądź intelektualnym. Te, choć po części spełnione, zamiast szczęścia przynoszą im poczucie samotności, wyobcowania i braku przynależności do określonego miejsca. Wykorzenienie przedstawia się w zerwaniu z żydowską tradycją. W szerszym kontekście losy mężczyzn odzwierciedlają powolny proces erozji żydowskich miasteczek w Europie ${ }^{14}$.

Bohaterów Berkowicza zaś badaczka podzieliła na trzy grupy. Do pierwszej z nich należą ci, którzy buntują się we własnym domu i pozostają w emocjonalnym cierpieniu lub całkowicie się załamują. Dom staje się dla nich pułapką, z której nie ma ucieczki. Koncept przyrównywania bohatera do więźnia Gowrin zauważa m.in. w utworach Ruchot Raot i Mi-Merchakim ${ }^{15}$. Druga grupa dotyczy osób, które wyjeżdżają do dużego miasta, polepszają swoje życie pod względem ekonomicznym, lecz po powrocie do domu odkrywają, że stali się w nim obcy i już nigdzie nie przynależą - np. Melafefonim i Talusz. Trzecia grupa odnosi się do bohaterów, którzy przewodzą ruchom rewolucyjnym, podążają za ideałami, by ostatecznie zrozumieć, że nie wytrzymują one próby rzeczywistości - np. Widuj oraz Be-nejchar ${ }^{16}$.

Z kolei talusze palestyńscy to pionierzy, syjoniści, którzy emigrują do Palestyny z nadzieją na przywrócenie w niej żydowskiego życia i utworzenie niepodległego państwa. Realia, jakie zastają po przybyciu do kraju trudności bytowe i adaptacyjne - skutkują rozczarowaniem, frustracją z powodu niespełnionych obietnic, przeżywaniem kolejnego „wygnania”. Wraz z rozwojem państwa nasilał się wśród nich dystans wobec diaspory,

\footnotetext{
13 Tamże, s. 345-346.

14 Gowrin, Tliszut..., s. 15-24.

15 Tamże, s. 63-64.

16 Tamże, s. 62-66.
} 
przez co Żydów europejskich zaczęli postrzegać w kategorii słabych fizycznie i psychicznie. Występują oni m.in. w opowiadaniach Josefa Chaima Brennera, Dwory Baron, Simchy Ben-Cijona i Meira Wilkanskiego ${ }^{17}$.

Do rozpowszechnienia się figury talusza przyczyniły się nastroje dekadenckie panujące wówczas w Europie. Nie bez powodu Chamutal Bar-Josef nazwała go „żydowskim dekadentem" ${ }^{18}$. Dekadentyzm bowiem znacznie przyczynił się do nadania wykorzenionemu takich cech, jak: fizyczna, moralna i psychiczna degeneracja, samotność, neurotyzm, pesymizm, niestabilność emocjonalna i uczucie życiowej pustki. Atrybuty te wyraźnie korelują ze skrajnym, trzecim wariantem wykorzenienia. Należy jednak zaznaczyć, że w wielu kwestiach talusz różni się od dekadenta. Obiera on w życiu jasny cel i dąży do jego realizacji lub podąża wybraną przez siebie ścieżką. Protagonista Brennera opiera swoje życie na syjonistycznej ideologii odrodzenia państwa żydowskiego (Misawiw la-nekuda), natomiast bohater Berdyczewskiego kieruje się racjonalizmem, logiką i myślą poznawczą (Machanajim). Warto dodać, że sylwetki „wykorzenionych” przypominają nieraz inne kreacje literackie, np. „flanera” czy „zbędnego człowieka"19. Z kolei dekadentki w literaturze europejskiej są przedstawiane najczęściej jako uwodzące, manipulujące mężczyznami femmes fatales, które prowadzą ich życie do zguby ${ }^{20}$. Są kobietami niezależnymi i wojowniczymi, płeć przeciwną traktują instrumentalnie celem zaspokojenia własnych żądz. Potrafią być okrutne i despotyczne. Ich atrybuty są z reguły przypisywane mężczyznom ${ }^{21}$. Co ciekawe, to właśnie kobiety w typie wampa lub intelektualnie wyzwolone są dla talusza najczęstszym obiektem westchnień2 ${ }^{22}$.

17 Tamże.

18 Chamutal Bar-Josef, Magaim szel dekadens, Bialik, Berdyczewski, Brener, Be'er Szewa 1997, s. 13-45; tenże, Mawo le-sifrut ha-dekadens be-Ejropa, Tel Awiw 1994, s. 45-56.

19 „Flaner był częścią subkultury obejmującej m.in. wędrowanie po mieście, rozmyślanie nad aspektem miejskiego życia i jego wielogodzinne obserwowanie. Kultura ta utożsamiana jest z bezcelowością, marnowaniem czasu”. Anna Zeidler-Janiszewska, Dryfujący flâneur, czyli o sytuacjonistycznej transformacji doświadczenia miejskiej przestrzeni, [w:] Przestrzeń, filozofia $i$ architektura. Osiem rozmów o poznawaniu, produkowaniu i konsumowaniu przestrzeni, red. Ewa Rewers, Poznań 1999, s. 125. Człowiek zbędny przedstawiany był w literaturze jako nobil przedkładający intelekt nad zdolność do czynu. Gowrin, Tliszut..., s. $19-20$.

${ }^{20}$ Marta Z. Bukała, Andronice Marii Komornickiej - między kreacją femme fatale a gnostycka transgresją, „Annales UMCS. Sectio FF, Philologiae” (2014), nr 32, s. 177.

${ }^{21}$ Tamże, s. 178-179.

22 W XX-wiecznej literaturze hebrajskiej przykładem femme fatale jest Wiera w utworze Gewer Jerachmiela Wajngartena. Z kolei u Jehudy Warszawiaka kobiety przedstawione 


\section{Stan badań nad kobietą wykorzenioną}

Temat bohatera wykorzenionego był skoncentrowany przede wszystkim na mężczyznach. Byli oni zarówno protagonistami utworów, ich twórcami, jak i odbiorcami. Wielu młodych Żydów mieszkających w diasporze łączył podobny bagaż doświaczeń, stali przed tymi samymi wyzwaniami, mieli porównywalne aspiracje. Zdaniem Shmuela Wersesa trudności młodych zwanych maskilim (zwolenników ruchu haskali) miały bezpośrednie przełożenie na typ kreowanych wówczas bohaterów ${ }^{23}$. Nie sposób zatem nie podzielać refleksji Joanny Lisek, której zdaniem „dyskurs patriarchalny skradł, zawłaszczył, zredukował i zdewaluował pojęcie kobiecości, a praca nad jego wyzwoleniem, rehabilitacją wciąż trwa"24. W odniesieniu do zawłaszczenia literatury przez mężczyzn warto także przywołać słowa Krystyny Kłosińskiej:

O twórczości kobiet pisze się w odniesieniu do uniwersalnego wzoru twórczości męskiej. Działa tu (odkryte przez dekonstrukcję) prawo, powszechne w praktyce interpretacyjnej, że opozycja binarna męski-żeński służy uznaniu jednej ze stron - męskiej - za ważniejszą i wartościowszą. Kluczowe jest tu słówko: „brak”. Definiowany przez „brak”, tekst kobiecy zostaje utożsamiony z defektem, ułomnością, niekompletnością (kastracją?). Cechę kompletności, pełni, mają produkty męskie 25 .

Temat kobiety wykorzenionej wart jest głębokich studiów, gdyż przez długie lata - mimo swej odmienności - nie była ona traktowana indywidualnie, lecz jako żeński odpowiednik talusza. Powstało niewiele opowiadań traktujących ten temat, jeszcze mniej zostało opracowanych. Artykuł stanowi próbę wypełnienia tejże luki i zapewnienia temu wątkowi odpowiedniego miejsca w dyskursie literackim.

są jako „krwiste, zdrowe, ponętne i wulgarne”. Magda S. Szwabowicz, Hebrajskie życie literackie w międzywojennej Polsce, Warszawa 2019, s. 323-324.

${ }^{23}$ „Hebrajski termin oznaczający oświeceniowy ruch i ideologię w społeczności żydowskiej mające swój początek w latach siedemdziesiątych XVIII w." Yehuda Slutsky, Judith R. Baskin, Haskalah, [w:] Encyclopaedia Judaica, vol. 8, red. Fred Skolnik, Michael Berenbaum, wyd. 2, Detroit 2007, s. 435; Shmuel Werses, Portrait of the Maskil as a Young Man, [w:] New Perspectives of the Haskalah, red. Shmuel Feiner, David Sorkin, London 2001, s. $128-129$.

${ }^{24}$ Joanna Lisek, Kol isze - głos kobiet w poezji jidysz (od XVI w. do 1939 r.), Sejny 2018, s. 16.

${ }^{25}$ Krystyna Kłosińska, Kobieta autorka: teoria literatury, krytyka, interpretacja, „Teksty Drugie" (1995), nr 3-4, s. 94-95. 
Począwszy od XIX w. powstało kilka utworów przedstawiających losy kobiet na tle osobistych dążeń w kierunku świeckiego wykształcenia, działalności publicznej, artystycznego sukcesu lub niezależności finansowej. Warto wymienić niektóre z nich: Be-jom ha-kipurim Dawida Friszmana (1880), Dor Tahpuchot Josefa Eliahu Triwosza (1881), Rabi Szifra Ben-Awigdora (1893), Bat ha-Aszir Aleksandra Zyskinda Rabinowicza (1899), Orwa Parach i Be-wejt Awiha (1900) Michy Josefa Berdyczewskiego, Neged ha-Zerem Jezajasza Berszadskiego (1901), Me'ewer la-chajim Simchy Ben-Cijona (1904), Genia Uriego Nissana Gnessina (1904) oraz Lewada Aarona Abrahama Kabaka (1905).

Warto nadmienić, iż tluszot (wykorzenione kobiety) - w przeciwieństwie do tluszim (wykorzenieni mężczyźni) - rzadko występowały w roli protagonistek opowiadań, częściej jako postaci drugo- lub trzecioplanowe.

Kobiecy bunt przeciwko tradycji nie przekładał się na jawną manifestację uczuć i poglądów. Swoje codzienne obowiązki wypełniały w niemym cierpieniu (np. Be-wejt Awiha Berdyczewskiego). W przeciwieństwie do mężczyzn ich pragnienie wyjazdu z miasteczka rzadko przekuwało się w czyn. Zazwyczaj kończyło się na snuciu wyobrażeń i fantazji o życiu gdzie indziej. Brakowało im odwagi, aby podjąć tak radykalne kroki. Znane są jednak nieliczne przypadki kobiet, które tego dokonały (Karet, Melafefonim). Co się tyczy motywacji, dla mężczyzn była nią przede wszystkim możliwość nauki na europejskich uniwersytetach (Talusz Berkowicza, Menachem Berdyczewskiego), a także aktywność w ruchach rewolucyjnych i ideowych (Widuj, Be-Nejchar Berkowicza). W przypadku kobiet odejście z domu oznaczało możliwość uniezależnienia się, samorozwój, wyzwolenie spod jarzma patriarchatu i żydowskiej obyczajowości, było wreszcie manifestacją indywidualizmu i drogą do poszukiwania własnego ,ja”. Przyczyną wyjazdu mogła być także ucieczka przed samotnością, utrata bliskich, bieda (Karet), a także strach powodowany niepewną sytuacją Żydów w Europie Wschodniej.

Wspólną cechą wszystkich bohaterów, zarówno kobiet, jak i mężczyzn, jest trwałe - niezależnie od miejsca pobytu - poczucie wyobcowania oraz zawieszenie pomiędzy skrajnie różnymi rzeczywistościami. Czują się obco zarówno w domu, w sztetlu, jak i w mieście. Karmią się wyobrażeniami o świecie, które nie mają pokrycia w realnym życiu. Bezzasadnie postrzegają siebie za lepszych, mądrzejszych od innych. Jednakże w kontakcie z innymi ich pewność siebie diametralnie spada. Jak zauważył Gershon Shaked, tluszot wrażliwością i emocjonalnym podejściem do życia przypominają 
swoich męskich odpowiedników. Popadają w podobne stany emocjonalne wynikające z braku przywiązania do miejsca, np. smutek, rozpacz, desperacja, poczucie bycia niezrozumianym przez innych. Eskalacja problemu u każdego - bez względu na płeć - charakteryzuje się stanem na pograniczu szaleństwa ${ }^{26}$.

W przeanalizowanym dotychczas materiale na próżno szukać informacji o recepcji utworów przedstawiających losy kobiet przez ówczesnych czytelników. Literatura ta nie odbiła się szerokim echem. Grono krytyków literackich wtedy działających było raczej niewielkie i w przeważającej większości składało się z mężczyzn, którzy koncentrowali się na podobnych doświadczeniach. Natomiast losy kobiet były im obce i nie poświęcali temu większej uwagi. Zagadnienie recepcji warto prześledzić w późniejszych latach. W 1914 r. Menachem M. Fajtelson opublikował jeden z pierwszych artykułów krytycznych na temat wizerunku „kobiety wyzwalającej się” w literaturze hebrajskiej ${ }^{27}$. Autor ten wyraża uznanie dla zajmowania się tym problemem przez współczesnych mu twórców, a także podkreśla duże znaczenie emancypacji kobiet. Stan badań nad mężczyzną wykorzenionym został omówiony w artykule Agaty Jaworskiej Na rozdrożu: Wizerunek bohatera wykorzenionego (talusz) na przykładzie prozy J. Ch. Brennera oraz M. J. Berdyczewskiego ${ }^{28}$. Natomiast jego żeński wariant był m.in. przedmiotem badań Avnera Holtzmana w obszernej monografii z 2006 r. zawierającej opracowanie utworu Berkowicza Melafefonim ${ }^{29}$. W opinii badacza bohaterka opowiadania, Szifra, jest karykaturą męskiej wersji talusza, ponieważ nie wykazuje się znajomością literatury naukowej. Zamiast tego preferuje ona lekturę rosyjskich klasyków, jest osobą naiwną i prowincjonalną. Mimo że nie wywodzi się z inteligencji, chciałaby, aby właśnie tak ją postrzegano.

W 2007 r. Yael Shenkar opublikowała pracę Ha-tluszot min ha-sifrut - Al mikuman szel naszim be-sifrut ha-tluszim [Wykorzenione

${ }^{26}$ Avner Holtzman, Anatomia szel tliszut: Al sipuro szel I. D. Berkowicz Melafefonim, [w:] Ahawot Cijon. Panim ba-sifrut ha-iwrit ha-chadasza, red. Avner Holtzman, Jeruszalajim 2006, s. 123.

${ }^{27}$ Menachem M. Fajtelson, Ha-isza ha-misztochreret be-sifrutenu, [w:] tenże, Ktawim. Sefer riszon, Jeruszalajim 1914, s. 79-101.

28 Jaworska, Na rozdrożu..., s. 23-37.

${ }^{29}$ Holtzman, Anatomia szel tliszut..., s. 119-135. O twórczości Berkowicza pisali także: Holtz, Isaac Dov Berkowitz...; Dan Miron, Bejn Icchak Dow Berkowicz li-wnej doro: Sziszim szana le-pirsum sipuro ha-riszon, [w:] tenże, Kiwun Orot, Tel Awiw 1979, s. 369-377; Gowrin, Tliszut..., s. 57-66. 
$\mathrm{z}$ literatury - o pozycji kobiet w literaturze wykorzenionych ${ }^{30}$. Badaczka przedstawiła w niej dwie podstawowe tezy dotyczące marginalizacji tematu kobiet w literaturze wykorzenionych. Zauważa, że nie dotyczyły ich rozterki nad naturą studiów, ponieważ zostały z góry pozbawione możliwości wyboru wykształcenia. Ponadto wskazała, że główną ówcześnie narracją była ta, która koncentrowała się na mężczyznach.

W 2011 r. Ronit Guez badała pozbawione korzeni postaci kobiece w pracy doktorskiej Sifrut naszim we-sifrut gwarim: masa u-matan al ha-naratiw ha-leumi [Literatura kobieca i męska: negocjacje nad narodową narracją $]^{31}$. Utwór Mariaszka Berkowicza przeanalizowała pod kątem zagadnienia płci w sztetlu, porównując go z Bat Israel Ja'akowa Steinberga oraz Pradel Dwory Baron. Z kolei Szifrę, bohaterkę Melafefonim, zaliczyła do grona tluszot $^{32}$. Nadrzędnej przyczyny oderwania Szifry od korzeni badaczka upatruje w powrocie do sztetla, który nasilił w niej pouczucie braku przynależności do tradycji, a dom stał się dla niej obcy i wrogi. Wszelkie zmiany, jakie zaszły w dziewczynie podczas życia w mieście, np. przyswojenie dobrych manier, zakup nowych ubrań czy pozyskana wiedza, zostały w sztetlu wyśmiane lub zlekceważone.

Dwa lata później, w 2013 r., ukazał się artykuł Heddy Shait The Female Rootless Character in Hebrew Prose: Initial Attempts at Shaping Her Image, w którym badaczaka, zestawiając wizerunki żydowskich kobiet z diaspory i Palestyny, udowodniła, że zjawisko wykorzenienia towarzyszy obu grupom bez względu na miejsce zamieszkania ${ }^{33}$. W przypadku bohaterek Szifry (Melafefonim) i Dwory (Karet) reguła ta sprawdza się zarówno w mieście, na prowincji, w Europie, jak i w Stanach Zjednoczonych.

${ }^{30}$ Yael Shenkar, Ha-tluszot min ha-sifrut - Al mikuman szel naszim be-sifrut ha-tluszim, [w:] Rega szel huledet. Mechkarim be-sifrut iwrit u-we-sifrut jidisz, red. Hannan Hever, Jeruszalajim 2007, s. 402-414.

${ }^{31}$ Ronit Guez, Sifrut naszim we-sifrut gwarim: masa u-matan al ha-naratiw ha-leumi, Be'er Szewa 2011, http://aranne5.bgu.ac.il/others/GuezRonit.pdf [dostęp: 19 listopada 2020].

${ }^{32}$ Wraz z protagonistkami utworów Orwa Parach Berdyczewskiego oraz Bchinot, Szokolad, Kico szel Sender Ziw Dwory Baron.

${ }^{33}$ Heddy Shait, The Female Rootless Character in Hebrew Prose: Initial Attempts at Shaping Her Image, „Women in Judaism” 10 (2013), nr 1, s. 1-23. 


\section{Kobieta żydowska w świecie zdominowanym przez mężczyzn}

Znikoma obecność kobiet w prozie omawianego okresu wynikała ze społecznych, historycznych, a także religijnych względów. Należałoby zatem się zastanowić, jakie mogły być tego źródła.

Pierwsze pokolenie haskali w Europie Wschodniej było symbolem duchowego rozdarcia, gdyż stało przed wyborem między chasydyzmem a stopniową laicyzacją. Młodzi, pogrążeni w kryzysie wiary mężczyźni coraz częściej decydowali się na wyjście z atmosfery tradycyjnego studiowania Tory i odrzucenie religijnego stylu życia na rzecz realizacji oświeceniowych ideałów. Jednakże lektura tekstów świeckich była w większości domów surowo zabraniana, krytykowana przez bogobojnych rodziców i piętnowana przez społeczność. Nieżydowski świat stanowił zagrożenie dla ich obyczajowości. Zmiana światopoglądu młodych Żydów powodowała kryzysy rodzinne i małżeńskie. Opuszczali oni swoje domy w poszukiwaniu podobnych sobie zwolenników ruchu oświeceniowego. Zdaniem Wersesa doświadczeni maskile oraz kult męskiej przyjaźni pomagały nowicjuszom w stopniowym przyswajaniu świeckiej wiedzy i adaptacji do nieżydowskiego świata ${ }^{34}$.Zamożni patroni wspierali młodych, opłacając długoletnie studia za granicą lub zapewniając im niezbędną literaturę. Wzmacniali ich także duchowo, inspirowali, wyrażali poparcie i motywowali do dalszej nauki. Domy patronów bywały miejscami spotkań i schronienia maskili ${ }^{35}$.

Prawo kobiet żydowskich do studiowania Tory i Talmudu jest wyraźnie ograniczone. Zgodnie z halachą nauka jest zarówno obowiązkiem, jak i przywilejem wyłącznie mężczyzn ${ }^{36}$. Przeświadczenie o niższości kobiety względem mężczyzny znajduje swoje źródło m.in. w Rdz 3, 12-24. Pierwsza kobieta, Ewa, ściągnęła na Adama gniew boży, przez co zostali wygnani z raju. Konsekwencje grzechu pierworodnego utrwaliły w żydowskiej

34 Werses, Portrait..., s. 130-132.

35 Tamże.

${ }^{36}$ „Rabi Eliezer mówi: »Każdy kto uczy swej córki Tory, to jakby uczył ją nieprzyzwoitości«". Słowo tiflut można tłumaczyć także jako 'błahość', 'lekkomyślność, 'sprośność', 'plugawość'. Marcus Jastrow, A Dictionary of the Targumim, the Talmud Babli and Yerushalmi, and the Midrashic Literature, https://www.tyndalearchive.com/TABS/Jastrow//? fbclid=IwA R2j4yjrWKrD2v5Ie_u04QLIAs19D9z3pYPSnHiUPS6c7VoLKsfNCmEnMbU [dostęp: 24 czerwca 2021]; Mishnah (Sotah 3:4), [w:] The Sefaria Library, https://www.sefaria.org/Mishnah_Sotah.3.4?lang=bi\&with=all\&lang2=en [dostęp: 8 kwietnia 2021]. „Prawna strona judaizmu obejmująca relacje osobiste, społeczne, krajowe i międzynarodowe oraz wszystkie inne praktyki i obrzędy judaizmu" - zob. Louis Jacobs, Halakhah, [w:] Encyclopaedia Judaica, wyd. 2, vol. 8, red. Fred Skolnik, Michael Berenbaum, Detroit 2007, s. 251. 
tradycji przekonanie o skłonności kobiet do zła, a kobiecą fizjologię powiązano z nieczystością ${ }^{37}$. Ze względu na predyspozycje biologiczne narzucono im z góry określoną rolę społeczną: bycie dobrą matką, żoną i gospodynią. Mimo to prokreacja jest w judaizmie postrzegana jako obowiązek męski, kobieta zaś powinna wspierać swojego męża w jego wypełnieniu ${ }^{38}$. Ponadto jest ona zobowiązana do przestrzegania zasad koszernej kuchni, czystości rodziny i wychowania licznego potomstwa w duchu jidyszkajt (żydowskości). Aby utrzymać rodzinę, zdarza się, że kobiety, których mężowie kontynuują studia religijne, są zmuszone podjąć pracę zarobkową, trudniąc się krawiectwem lub handlem. Większość z nich jest odseparowana od życia religijnego. W synagogach zajmują wyznaczone miejsce zwane babińcem. Znajomość języka hebrajskiego jest wśród nich rzadkością, są zatem wykluczone z udziału w liturgii. Korzystają z modlitewników napisanych w jidysz, tzw. tchines $^{39}$. Religijność kultywują samotnie, w ich przypadku minjan (kworum modlitewne) nie jest wymagany. Najważniejsze rytuały religijne, które sprawują, to zapalanie świec szabatowych (hadlakat ha-nerot), zachowanie czystości cielesnej poprzez kąpiel rytualną (nida) oraz oddzielanie dziesiątej części ciasta na chałę (chala ${ }^{40}$.

W hierarchii społeczności żydowskiej kobiety zajmują niską pozycję, co wynika z głęboko zakorzenionego porządku patriarchalnego. Pierwszym człowiekiem stworzonym przez Boga był mężczyzna, kobieta zaś powstała z jego żebra (Rdz 2, 21-23), a zatem skazana została na drugorzędność. W podstawowych tektstach judaizmu kobiety niejednokrotnie przedstawia się jako mniej wartościowe: „Szczęśliwy, kto ma samych synów, biedny, kto ma same córki" ${ }^{41}$. O ich losie, np. w kwestii zamążpójścia, rozwodu, dziedziczenia, decydują zazwyczaj ojcowie, bracia lub mężowie ${ }^{42}$. Sytua-

${ }^{37}$ Israel Bartal, Haskalah Literature: Portrayal of Women, [w:] The Jewish Women's Archive, https://jwa.org/encyclopedia/article/haskalah-literature-portrayal-of-women [dostęp: 30 czerwca 2021].

${ }^{38}$ Mishnah (Yevamot 65b, 5), [w:] The Sefaria Library, https://www.sefaria.org/Yevamo t.65b.4?lang=bi\&with=all\&lang2=en [dostęp: 4 lipca 2021].

${ }^{39}$ Lisek, Kol isze..., s. 108-121.

${ }^{40}$ Mishnah (Niddah 1, 1-2), [w:] The Sefaria Library, https://www.sefaria.org/Mishnah Niddah.1?lang=bi [dostęp: 28 czerwca 2021]; Mishnah (Shabbat 2, 6-7), [w:] The Sefaria Library, https://www.sefaria.org/Mishnah_Shabbat.1?lang=bi [dostęp: 28 czerwca 2021].

${ }^{41}$ Mishnah (Sanhedrin 100b, 5-6), [w:] The Sefaria Library, https://www.sefaria.org/ Sanhedrin.100b?lang=bi [dostęp: 2 lipca 2021]; Mishnah (Kiddushin 82b, 2), [w:] The Sefaria Library, https://www.sefaria.org/Kiddushin.82b.2?lang=bi\&with=all\&lang2=en [dostęp: 2 lipca 2021].

${ }^{42}$ Mishnah (Yevamot 106a, 17), [w:] The Sefaria Library, https://www.sefaria.org/ Yevamot.106a.17?vhe=Wikisource_Talmud_Bavli\&lang=bi [dostęp: 28 czerwca 2021]. 
cja kobiet zależy także od ich statusu społecznego. Te, które pochodzą $\mathrm{z}$ majętnych rodzin, mają większe możliwości rozwoju.

Pierwsze pokolenie maskilim, zdaniem Tovy Cohen, utorowało drogę kolejnym, w tym także kobietom ${ }^{43}$. Obowiązek edukacji przedstawicieli obojga płci był jednym z podstawowych wątków dyskursu zarówno zwolenników haskali, jak i żydowskiego socjalizmu. Mimo głoszonych przez nich postulatów, m.in. uniezależnienia się finansowego kobiet, prawa do akulturacji i należytego im szacunku, nie traktowano kobiet jako równoprawnych zwolenniczek ruchu postępowego. Potrzeba i rola edukacji w ich życiu nie została jednoznacznie skrystalizowana przez maskilów ${ }^{44}$. Mimo wspierania kobiecej działalności kulturalnej, a nawet zakładania żeńskich szkół obecność kobiet na płaszczyźnie kulturowej, duchowej i religijnej była w dalszym ciągu wykluczana. Ich wykształcenie nie było nadrzędnym celem działań oświeconych kręgów męskich, lecz jednym z wielu elementów wyższej idei, czyli stworzenia wykształconego i zasymilowanego narodu żydowskiego w Europie ${ }^{45}$. Kobiety poszukujące wiedzy lub pisarki stanowiły jedynie ciekawostkę. Postępowe środowiska czytelnicze i wydawnicze pozostały zdominowane przez mężczyzn. Joanna Lisek w swojej publikacji Kol isze zwraca uwagę na „potrójną marginalizację” kobiet żydowskich. Reprezentowały one zarówno mniejszość narodową, jak i religijną. Żyły w społeczeństwie opartym na dominującej pozycji mężczyzny, a ich twórczość była wtedy postrzegana jako błaha i pozbawiona siły przebicia ${ }^{46}$.

Niewiele kobiet miało dostęp do edukacji świeckiej, a jeszcze mniej do religijnej. Zdarzało się, że zamożni ojcowie, najczęściej maskile, najmowali prywatnych nauczycieli, aby uczyli ich córki języków europejskich, np. francuskiego czy rosyjskiego. Wyjątkiem byli wschodnioeuropejscy maskile, którzy dokładali starań, by poza sztuką, naukami świeckimi córki uczono także hebrajskiego oraz podstaw Bibliii ${ }^{47}$. Ruch haskali był na tych ziemiach wyjątkowo silnie związany z żydowską tradycją i hebrajszczyzną. Fakt ten Cohen komentuje następująco: „Język hebrajski i żydowskie teksty kanoniczne pozostały fundamentem, na którym opierała się nowa kultura

43 Tova Cohen, Portrait of the Maskilah as a Young Woman, „Nashim” (2008), nr 15, s. $13-15$.

44 Tamże, s. 10.

45 Shmuel Feiner, Haskalah Attitudes Toward Women, [w:] Jewish Women's Archive, https://jwa.org/encyclopedia/article/haskalah-attitudes-toward-women [dostęp: 30 czerwca 2021].

${ }^{46}$ Lisek, Kol isze..., s. 16.

47 Cohen, Portrait..., s. 21. 


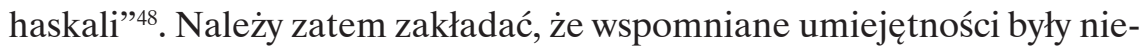
odzowne, aby zostać maskilą (oświeconą). Cohen wymienia przykłady kobiet, które za takowe się uważały i działały w duchu oświeceniowym ${ }^{49}$. Dowodem na to są m.in. zachowana korespondencja, eseje, przekłady, proza.

Warto podkreślić, że edukacja kobiet nie była kontrolowana przez otoczenie w tak dużym stopniu, jak w przypadku mężczyzn. Iris Parush wskazuje, że dzięki temu miały one dużą swobodę doboru lektur ${ }^{50}$. Uczyły się za zgodą ojca, nie musiały ukrywać swoich zainteresowań ani opuszczać domu. Co więcej, ojcowskie wsparcie umacniało ich relacje z rodziną. Natomiast bliska więź z nauczycielem przyczyniała się do podejmowania dalszej, indywidualnej i systematycznej nauki.

Mężczyźni z kolei wiedzę z zakresu nauk świeckich zdobywali samodzielnie lub z pomocą doświadczonych maskili, zazwyczaj po kryjomu, wbrew woli rodziców. Dostęp do literatury niereligijnej był jednak bardzo ograniczony. W chederach i jesziwach uczyli się oni hebrajskiego, a także tekstów kanonicznych, głównie Tory i Talmudu, oraz późniejszej literatury halachicznej. Nauka języka była pamięciowa i niesystematyczna, gramatykę opanowywali często samodzielnie. Ich znajomość hebrajskiego stanowiła zatem jedynie punkt wyjścia do zdobycia większej biegłości językowej.

Jak wynika z powyższej analizy, bunt mężczyzn przeciwko tradycji był silnie krytykowany przez społeczność, co pozwala wnioskować, że w przypadku kobiet krytyka byłaby dotkliwsza. Należy pamiętać, że dziewczęta z ubogich domów były pozbawione możliwości nauki, nie dręczyły ich zatem wątpliwości, czy podążać świecką, czy religijną drogą. W przeciwieństwie do mężczyzn wykształcone kobiety pozostawały w tym samym świecie, z którego pochodziły. Nawet jeśli podzielały one poglądy oświeceniowe, nie zawsze ośmielały się lub miały szansę je urzeczywistnić. Wiele z nich rezygnowało z dalszej edukacji i kariery na rzecz małżeństwa, opieki nad dziećmi i dbania o potrzeby gospodarstwa domowego. Dążenie kobiet do studiowania świeckich pism lub decyzja o opuszczeniu miasteczka z innych powodów nie przerodziły się w odrębne, znane zjawisko.

48 Tamże.

49 Miriam Markel Mosessohn, Rachel Morpurgo, Sara-Feiga Meinkin-Foner, Nehama Feinshtein oraz Olga Belkind. Tamże, s. 23; Dan Miron, Why Was There No Women's Poetry in Hebrew Before 1920?, [w:] Gender and Text in Modern Hebrew and Yiddish Literature, red. Naomi B. Sokoloff, Anne Lapidus-Lerner, Anita Norich, New York 1992, s. 65-93.

${ }^{50}$ Iris Parush, Reading Jewish Women: Marginality and Modernization in Nineteenth-Century Eastern European Jewish Society, Waltham 2004, s. 62-70. 


\section{Zarys postaci bohaterek Berkowicza}

Berkowicz był przedstawicielem hebrajskiego realizmu zapoczątkowanego przez warszawską grupę literacką Ha-Mahalach he-Chadasz [Nowy Prąd], której liderem był Awraham Lejb Szalkowicz znany jako Ben-Awigdor ${ }^{51}$. Jej aspiracją było dotarcie do żydowskich mas za pomocą tzw. literatury dla nich i o nich odzwierciedlającej rzeczywistość, której sami byli częścią, a także niskich cen publikacji ${ }^{52}$. Nowy Prąd promował utwory realistyczne, naturalistyczne, odarte z patosu i dekoracyjnych epitetów. Grupa utorowała droge pisarzom urodzonym w Europie w latach siedemdziesiątych i osiemdziesiątych XIX w. Byli to m.in. Chajim Nachman Bialik, Simcha Ben-Cijon, Aaron Abraham Kabak, Icchak Dow Berkowicz, Aszer Barasz, Ja'akow Rabinowicz i Szlomo Cemach. W swoich dziełach koncentrowali się oni przede wszystkim na temacie przemian w społeczeństwie żydowskim, upadku religii i tradycji.

Utworów Berkowicza, w których kobiety odgrywają pierwszo- lub drugoplanową rolę, jest niewiele. Są to głównie: Mariaszka, Ruchot Raot, Melafefonim i Karet. Należy się jednak zastanowić nad tym, czy wszystkie z nich można zaliczyć do grona wykorzenionych.

Zlatka (Ruchot Raot) buntuje się we własnym domu przeciwko panującej w nim nędzy, upadkowi moralnemu rodziny, dotkniętemu chorobą psychiczną ojcu i niemożności zapanowania nad licznym rodzeństwem. Podczas próby ucieczki zostaje siłą powstrzymana przez braci. Popada w obłęd i pozostaje w emocjonalnej rozpaczy. Z kolei Mariaszka (Mariaszka), młoda dziewczyna pracująca jako pokojówka, zostaje zwabiona urokiem starszego od niej nauczyciela, Lewisona, a następnie przez

${ }^{51}$ Jej działalność oraz styl postrzegano jako drugorzędne. Prym wiódł ówcześnie realizm społeczny z elementami satyryczno-sentymentalnymi Mendelego Mojchera Sforima oraz hebrajski romantyzm reprezentowany przez Dawida Friszmana, Icchoka Lejba Pereca, Michy Josefa Berdyczewskiego i Mordechaja Ze'ewa Fajerberga. W późniejszych latach popularna stała się także proza psychologiczna tworzona głównie przez reprezentantów jiszuwu: Josefa Chaima Brennera, Hirsza Dawida Nomberga, Uriego Nissana Gnessina, Gerszona Szofmana, Ja'akowa Sztajnberga oraz Dwory Baron. Gershon Shaked, Modern Hebrew Fiction, thum. Yael Lotan, red. Emily Miller Budick, Bloomington 2000, s. 37-38; Szwabowicz, Hebrajskie życie..., s. 49-51.

${ }^{52} \mathrm{Na}$ niską cenę wskazuje nazwa serii: Sifrej agora (groszowe książki). Dziełem, które manifestowało poglądy ugrupowania, był utwór Ben-Awigdora Lea mocheret ha-dagim [Lea handlarka ryb]. Sifrej ha-agora spotkała się z krytyką ze strony starszego pokolenia pohaskalowego prezentującego sztywne normy literackie (nusach) oraz dość archaiczny język. Tamże, s. 45. 
niego wykorzystana. Skrzywdzona, pohańbiona i zrozpaczona, uświadamia sobie, że podobnie jak jej rodzicom będzie jej dane wieść nędzne życie.

Jedynie w przypadku losów Szifry (Melafefonim) i Dwory (Karet) zjawisko wykorzenienia zostało wyraźnie uwypuklone przez autora. Pozostałe bohaterki nie znają innego świata niż żydowskie miasteczko. Doświadczyły życia w jednej przestrzeni, nie mają możliwości porównania jej z inną.

Każda z nich jest ofiarą sytuacji społecznej, psychologicznej lub religijnej. Nie są w stanie zapobiec swojej ostatecznej zgubie i fatalnemu przeznaczeniu. Wszelkie próby wyjścia z tragicznego położenia są z góry skazane na klęskę. Gdziekolwiek się znajdą, czują się wyobcowane, zdystansowane zarówno w geograficznym, jak i psychologicznym sensie. Bez względu na zmieniające się w tle wydarzenia uczucie to jest trwałe i narasta, aby ostatecznie doprowadzić je do obłędu. Postacie cierpią z powodu wykluczenia, bezsilności, pustki i samotności. W rezultacie rozważają popełnienie samobójstwa, które wydaje im się jedyną możliwą ucieczką przed przeznaczeniem. Ostatecznie, nie mając innego wyboru, akceptują swój los.

\section{Karet [Wygnanie]}

Omawiany motyw wykorzenienia jest obecny w utworze Berkowicza Karet $^{53}$. Tytuł utworu należy rozumieć jako odcięcie, zdystansowanie się. W Biblii termin karet nawiązuje do kary z nieba, przedwczesnej śmierci grzesznika lub ekskomuniki ${ }^{54}$. Z punktu widzenia bohaterki oznacza on karę nałożoną na nią za opuszczenie miasteczka, a tym samym - odejście od religii: „Za swoje grzechy! Zaciągnęłam swoje stare kości do Ameryki”. Ponadto nawiązuje do metaforycznego znaczenia wyrazu talusz, który w tym kontekście należy rozumieć jako odcięcie korzeni syna, a zatem także amerykańskich Żydów, od konwencjonalnych, żydowskich wartości ${ }^{55}$.

Utwór jest przykładem nie tylko upadku europejskiego sztetla, ale i trudności adaptacyjnych Żydów masowo migrujących do Stanów Zjednoczonych na początku XX w. W opowiadaniu autor uwypuklił szok

${ }^{53}$ Berkowicz, Sipurim niwcharim..., s. 161-180.

54 'Ścinać, np. drzewo, 'odcinać', 'odseparować, 'odizolować, 'przedwczesna śmierć z powodu grzechu'. Oxford English-Hebrew and Hebrew-English Dictionary..., s. 138.

${ }^{55} \mathrm{~W}$ literaturze rabinicznej termin talusz odnosi się do zbiorów, określa plon - wyrwane z ziemi zboże, którego ziarno pozostaje w kłosie, lub owoce zerwane z drzewa, ale nieobrane z łupiny. Halkin, Mawo..., s. 343. 
społeczno-kulturowy, jaki im wówczas towarzyszył. Jego protagonistka, znajdująca się u schyłku życia Dwora Rabinowicz, jest samotną wdową; wszystkie jej dzieci z wyjątkiem syna, który wyemigrował do Ameryki, zmarły. Po niemal całym życiu spędzonym w sztetlu wyjeżdża, aby z nim zamieszkać, żywi bowiem nadzieję na lepszy los u jego boku. Podróż ilustruje jej wewnętrzne rozterki, bolesne wspomnienia z przeszłości związane ze śmiercią najbliższych, a także strach przed nieznanym.

Analogicznie do wykorzenionych mężczyzn bohaterka jest silnie związana z tradycją, z której się wywodzi. Wyjazd do Ameryki jest równoznaczny z zerwaniem z przyjętymi w sztetlu zasadami, zgodnie z którymi żyła przez lata. Należy jednak podkreślić, że powód opuszczenia rodzinnej miejscowości jest inny i motywowany dojmującą pustką po stracie bliskich. Jako osoba w podeszłym wieku bohaterka nie wyjeżdża w pogoni za edukacją czy poznawaniem świata. Zmiana ta wyrywa ją ze spokojnej, monotonnej codzienności i wciąga w wir nowego, obcego i przerażającego świata. Zgiełk, tłumy pasażerów mówiących w różnych językach przywodzą jej na myśl sceny biblijne, m.in. legendę o wieży Babel i losy Żydów w czasach niewoli egipskiej i babilońskiej. Możemy mówić o swego rodzaju traumie, jakiej doświadcza przy zderzeniu się z zupełnie innym, a co za tym idzie - tak bardzo dla niej niezrozumiałym światem. Pogrążona w smutku i osamotnieniu kobieta z nostalgią wspomina przeszłość. Odczuwa wyrzuty sumienia względem umarłych, których opuściła: „Stali, patrząc na nią z cichego wzgórza cmentarnego, bielejącego niskimi nagrobkami, wyglądali spomiędzy zielonych drzew i kiwali za nią głowami: Dokąd? Dokąd przed nami uciekasz?" 56 . W głębi serca czuje, że dokonała złego wyboru: „Nie była w stanie zrozumieć, co tu robi ani dokąd prowadził ją jej kręty w ostatnich dniach życia los. Jedyną myślą, która lśniła jak iskra w nocy, było wspomnienie o jej synu w Ameryce”; „w wielkiej niepewności, zawahała się, zadając sobie pytanie, czy nie popełniła błędu"57. Podróż bohaterki należy z jednej strony odczytywać jako fizyczną zmianę miejsca, z drugiej zaś jako duchowe przejście pomiędzy dwoma środowiskami.

Porównywalnie do bohaterów Berdyczewskiego (Lewadad, Menachem, Ha-Zar) w nowym miejscu Dwora odczuwa silne wyobcowanie. Kolejne wydarzenia budują jednoznaczne przesłanie opowieści, tj. nieudaną próbę asymilacji do życia w nowym świecie. Kobieta trafia do domu, w którym język, zwyczaje i atmosfera są jej zupełnie obce. $Z$ trudem rozpoznaje syna,

${ }^{56}$ Berkowicz, Sipurim niwcharim..., s. 161.

57 Tamże. 
ponieważ jego wygląd zmienił się przez lata. Zdaje się jej, że jest „obcym człowiekiem”, zaskakuje ją „dziwny blask złota jego zębów” oraz „dziwna, ogolona twarz". Złote zęby podkreślają zmianę wartości, jaka zaszła w jego życiu - stał się materialistą: „Czy zdajesz sobie sprawę, kochana mamo, że jestem tu bogatym człowiekiem?”; „Nie mogłabyś mnie wykupić za sto tysięcy dolarów" ${ }^{58}$. Kobieta jest skazana na słuchanie o majątku, który zebrał. Im bardziej syn obnosi się ze swoim dobrobytem, tym silniej matka odczuwa pogłębiającą się między nimi przepaść: „Stara kobieta słuchała tych wszystkich dziwnych słów, kiwając głową zamożnemu i zadowolonemu z siebie synowi, uśmiechając się smutnym i zrezygnowanym uśmiechem"59. Motyw złota pojawia się w utworze wielokrotnie, np. złote zęby, okulary, litery na nagrobkach. Symbolizuje ono materializm amerykańskich Żydów, którzy porzucili tradycyjne wartości.

Synowa unika Dwory i nie ułatwia jej adaptacji w nowym domu. Nie pochwala jakichkolwiek śladów żydowskich korzeni. Sprzeciwia się nazywaniu jej żydowskim imieniem Fajga-Lea. Wygląd i sposób bycia synów pary także uosabiają dwa światy: świecki i tradycyjny. Starszy, podobnie jak jego matka, jest wycofany i zdystansowany: „Uprzejmie pocałował ją w policzek jak ktoś, kto umie spełnić obowiązek" ${ }^{60}$. Młodszy z kolei jest podekscytowany wizytą babci, okazuje jej sympatię i uwagę. Wspomniany podział w rodzinie należy odczytywać jako przejście z pełnego obrzędów, religijnego, żydowskiego domu do obcego, zobojętniałego, pozbawionego tradycji przodków środowiska. Reprezentantką „starych” wartości jest Dwora będąca symbolem chylącego się ku upadkowi świata religijnych Żydów. Zarówno jej wygląd, jak i zwyczaje wydają się domownikom dziwaczne i nieprzystające do nich: „W czarnej chustce, obszernej, staromodnej i czarnej sukni wygląda jakby była tylko gościem, jakby miała wkrótce zabrać swoje rzeczy i wyjść" ${ }^{61}$.

Wymownym symbolem w opowiadaniu jest kufer Dwory - „spuścizna po mężu” - wypełniony podarunkami dla rodziny syna, tj. starymi, religijnymi księgami i parą srebrnych świeczników. Stanowi on metaforę tożsamości kobiety, a zarazem jej życiowej traumy. Żywiła bowiem nadzieję, że przedmioty te staną się łącznikiem pomiędzy jej przeszłością a teraźniejszością, fundamentem, na którym oprze swoje nowe życie. Kufer

\footnotetext{
58 Tamże, s. 162.

59 Tamże.

60 Tamże, s. 163.

61 Tamże.
} 
jest dla niej namiastką bezpieczeństwa: „Szukając wsparcia w tym obcym otoczeniu, chwyciła kufer stojący u jej stóp"62. Jego obecność w świeckiej przestrzeni ma przywrócić tradycyjne zwyczaje w domu syna, a w szerszym kontekście - także wśród innych żydowskich rodzin żyjących „na wygnaniu". Przedmioty nie są jednak przyjęte $z$ entuzjazmem i zostają kobiecie zwrócone: „Następnego dnia Dwora znajduje świeczniki na stole w swoim pokoju”; „Starszy chłopiec otworzył dziwną książeczkę i po przejrzeniu bez przekonania włożył ją z powrotem do kufra" ${ }^{63}$. Należy domniemywać, że odrzucenie prezentów jest tożsame z odtrąceniem kobiety wraz z jej światopoglądem, a także $\mathrm{z}$ ignorancją wobec tradycyjnego świata pojęć.

Analogicznie do losów klasycznej wersji talusza bohaterka zostaje skazana na samotność. Próbowała przed nią uciec ze sztetla, lecz u boku syna uczucie to paradoksalnie wzmocniło się: „Bez celu wędrowała schylona i zatroskana przez eleganckie pokoje, jakby czegoś szukała, lub siedziała godzinami przy końcu stołu w swoim pokoju" ${ }^{64}$. Berkowicz przyrównuje kobietę do więźnia, podkreślając brak możliwości ucieczki, wyobcowanie i niemożność zmiany jej położenia: „Niczym więzień przy oknie w swojej celi stała nieruchomo w niemej modlitwie do dalekiego, niewidzialnego Boga za morzami w jej odległej mieścinie w Europie"65. Wraz z rozwojem opowieści kolejne przyczyny wyobcowania nakładają się na siebie, potęgując tragedię głównej bohaterki. Rodzina syna nie prowadzi - pomimo wcześniejszych zapewnień - koszernej kuchni, co skutkuje wyrzuceniem Dwory poza nawias domowego porządku: „Zawstydzona i w poczuciu winy stała w kącie kuchni, w milczeniu przygotowując swoje posiłki. Potem zabierała jedzenie do swojego pokoju i siedziała tam, wpatrując się w miskę w milczeniu przez wiele godzin" ${ }^{\prime 6}$. Kolejnym dla niej zawodem okazuje się wizyta w synagodze. Żywiła nadzieję, że tam nareszcie odnajdzie upragnioną równowagę i poczucie bezpieczeństwa. Zamiast tego zderza się z ignorancją wobec świętości i hedonizmem wspólnoty: „W gorącej, dusznej atmosferze wiał chłodny wiatr herezji” ${ }^{\prime 7}$. Jednakże prawdziwie kryzysowym doświadczeniem jest udział w uroczystości pogrzebowej. Podczas ceremonii zauważa bowiem obojętność wiernych, brak oznak żałoby i pośpiech: „Syn zmarłego uśmiechnął się szeroko i pokazał

\footnotetext{
${ }^{62}$ Tamże, s. 164.

${ }_{63}$ Tamże, s. 166.

${ }^{64}$ Tamże, s. 168.

${ }^{65}$ Tamże, s. 177.

${ }_{66}$ Tamże, s. 178.

${ }^{67}$ Tamże.
} 
swoje złote zęby. Potem przypomniał sobie, że nie powinien śmiać się razem z innymi i przybrał poważny wyraz twarzy" ${ }^{68}$. Razi ją nieobeznanie w obrządkach i brak poszanowania wielowiekowej tradycji, np. nieznajomość słów kadiszu, nieadekwatność poematu Akdamut towarzyszącego pochówkowi, cmentarz będący mozaiką żydowskich i chrześcijańskich nagrobków ${ }^{69}$. Wszystko to odbiera kobiecie resztkę chęci do życia.

Ostatnia, wymowna scena utworu przedstawia jej krańcowe rozgoryczenie, stan na pograniczu szaleństwa i histerii: „Siedziała w dziwnej pozycji na kufrze książek, pochyliła się, potrząsając głową schowaną w dłoniach, cicho jęcząc, była jak nieszczęsna sierota opuszczona przez człowieka i Boga"70. Ostatecznie kobiecie nie pozostaje nic innego, jak pogodzić się ze swoim losem.

\section{Melafefonim [Ogórki]}

Zjawisko wykorzenienia występuje także w opowiadaniu Berkowicza pt. Melafefonim $^{71}$. Jego główną bohaterką jest Szifra, która tak jak większość tluszim wyjechała do miasta w celu polepszenia sobie warunków życia. To postać ciekawa świata, dążąca do finansowej niezależności. Podobnie jak dla Dwory przeprowadzka do metropolii nie wiązała się w jej przypadku z kwestią edukacji, lecz pracy. Po latach spędzonych w Warszawie, gdzie pracowała jako szwaczka, postanowiła powrócić do sztetla. Analogicznie do losów doktora Wajnika (Talusz) pobyt w mieście nie uszczęśliwił Szifry, poprawił jedynie jej pozycję ekonomiczną. Jednakże największą jej udręką nie była nostalgia i tęsknota za domem - tak jak w przypadku Isschara-Bera (Mi-Merchakim) - lecz samotność: „Zrozumiała, że jest samotna w dużym mieście, ponieważ wszystko w nim jest jej obce i dzień po dniu staje się coraz starsza w tym osamotnieniu" "72.

Ronit Guez, analizując losy bohaterki, wymieniła trzy główne różnice między nią a wykorzenionymi mężczyznami. Pierwszą jest pozbawienie Szifry tradycyjnej edukacji w dzieciństwie. Drugą są odmienne zapatrywania na kwestię miłości. Mężczyźni dążyli do pozyskania kontroli nad kobietą i prezentowania niezachwianej męskości (Lewadad). W przypadku kobiet

\footnotetext{
68 Tamże, s. 179.

${ }^{69}$ Akdamut to pijut śpiewany podczas radosnego święta zbiorów - Szawuot.

70 Tamże, s. 180.

${ }^{71}$ Berkowicz, Sipurim..., s. 45-79. Oryginalny tytuł utworu brzmiał Jerakot [Warzywa].

72 Tamże, s. 45.
} 
romantyczna miłość miała przyczynić się do zmiany statusu społecznego i uwolnienia się z kajdan patriarchatu. Szifra poszukuje miłości idealnej, urzeczywistnienia prezentowanego w literaturze rosyjskiej modelu miłości. Trzecia różnica wskazuje na stosunek tradycyjnego świata żydowskiego do obcej kultury i świeckiej edukacji. W tradycyjnym rozumieniu miały one negatywny wpływ na związek młodego mężczyzny z religią, wyznaniem i przynależnością narodową. Stosunek tradycjonalistów do młodych kobiet starających się zdobyć wykształcenie był w istocie inny. Lektura literatury rosyjskiej lub jidysz nie zagrażała tak bardzo społecznemu ładowi ${ }^{73}$.

Avner Holtzman z kolei w postaci Szifry upatrywał nieudanej, karykaturalnej, żeńskiej wersji talusza ${ }^{74}$. Uzasadniając swoją tezę, wskazał na zamiłowanie dziewczyny do lektury rosyjskich romansów zamiast do literatury naukowej, a także na jej braki edukacyjne, czego przykładem jest nieumiejętność odróżnienia podręcznika do socjologii od powieści Turgieniewa. Zdaniem badacza - krytyka, której poddaje bohaterka tradycjonalizm swoich przodków, jak i jej umiłowanie świeckiej edukacji wywołują parodystyczny efekt. Dziewczyna nazywa swego ojca „zupełnym fanatykiem”, a pokolenie rodziców - „pogrążonym w ciemności”. Niemniej, podczas dyskusji z ojcem potrzebę czytania Szifra argumentuje niezbyt przekonująco: „Każdy, kto czyta - wiele z tego ma... Czerpie mądrość i wykształcenie. [...] można wyjść do ludzi, zacząć rozmowę i wyrazić jakąś swoją opinię" "75. Zdaniem Holtzmana Szifra jest arogancka, wyniosła i protekcjonalna, samą siebie postrzega jako lepszą od innych.

Jeszurun Keszet natomiast zarzucił Berkowiczowi, że zarówno ośmieszenie bohaterki, jak i uwypuklenie jej łatwowierności było celowe i bezlitosne. Pisarz kategorycznie sprzeciwił się takiej interpretacji, twierdząc, że jego stosunek do postaci Szifry nie był okrutny, lecz współczujący ${ }^{76}$.

Lata pobytu w mieście zmieniły wygląd, jak również zachowanie Szifry. Jawi się jako elegancko ubrana dziewczyna, zakłada „szeroki kapelusz z dużym piórem i białe rękawiczki”, jest uśmiechnięta i pełna otuchy. Domownicy traktują ją jak „szacownego gościa”. Przywiezione przez nią przedmioty zachwycają jej liczne rodzeństwo: „białe buciki z gumy do tańca”, „wachlarz”, „elegancka suknia z czarnego jedwabiu”, „piękny niebieski płaszcz uszyty z krepy i muślinu”, „szczoteczka przeznaczona

\footnotetext{
${ }^{73}$ Guez, Sifrut naszim ..., s. 100-109.

74 Holtzman, Anatomia szel tliszut..., s. 130-135.

75 Berkowicz, Sipurim..., s. 71.

76 Jeszurun Keszet, Be-dor ole: Masot al I. D. Berkowicz, Tel Awiw 1950, s. 35-36.
} 
do mycia zębów” czy „zapieczętowana puszka kakao”. Ojciec nie wierzy w prawdziwość przywiezionego przez córkę kakao, nazywając je „zwykłą cykorią". W postępie cywilizacyjnym mężczyzna upatruje zagrożenia dla „starego" świata tradycji. Ich sprzeczka przypomina dyskusje toczące się między postępowymi maskilami a ich konserwatywnymi ojcami. Zauważalna jest także męska obawa przed utratą kontroli nad młodymi, emancypującymi się kobietami i zachowaniem tradycyjnego podziału ról ze względu na płeć.

Potrzeby, wygląd i styl bycia Szifry znacznie różnią się od zwyczajów przyjętych w domu. Dba ona o higienę, nosi czyste ubrania, używa „białej serwetki” podczas posiłku i czyta książki. Dziewczyna dostrzega zmiany, jakie zaszły w gospodarstwie podczas jej nieobecności, i odczuwa rosnący dystans pomiędzy sobą a domownikami. Jest wstrząśnięta wyglądem zrujnowanego i zaniedbanego domu:

Zaczęła się rozglądać [...] po gołych i krzywych ścianach, niskim, okopconym suficie, po ciemnych kątach, do których nie dopuszczają światła stare pajęczyny pokryte czarnym kurzem i zaplątanymi w nie muchami. W domu unosił się zapach zgnilizny, pomyj i brudnej bielizny. Łóżka nie zostały jeszcze zaścielone, a na ławki rzucono stos starych i wymiętych poduszek, prześcieradeł i kołder, z których wystawały pióra i puch - a bieda czyniła je jeszcze nędzniejszymi ${ }^{77}$.

Podobne poczucie pogardy dla nędzy panującej w żydowskich domach towarzyszyło mężczyznom, którzy powracali po latach w rodzinne strony (Mi-Merchakim, Talusz). Szifra stara się odizolować od wszechobecnego brudu i nieporządku: „Chodzi po domu w swojej czystej, białej sukience, odizolowana od wszystkiego, co się w nim dzieje" 78 . Wygląd jego wnętrza jest przeciwieństwem piękna natury otaczającej go z zewnątrz. Ruina, w którą się zamienił, odzwierciedla zniszczone relacje międzyludzkie, brak poczucia bezpieczeństwa i stabilizacji. W szerszym kontekście symbolizuje upadek żydostwa w Europie. Rozmowy domowników ograniczają się do tematu pracy i obowiązków. Atmosfera jest napięta, pełna wzajemnych roszczeń i pokrzykiwań. Dzieci są pozostawione samym sobie. W rodzinie brakuje wsparcia, miłości i wzajemnej opieki. Każdy z jej członków jest samotny i nieszczęśliwy: „Ojciec siedział milczący i przygnębiony z powodu mocnego kaszlu. Jego twarz miała kamienny i posępny wyraz, a oczy były mętne [...], patrzyły bez iskry i bezmyślnie” 79 , „matka chciała opowiedzieć

${ }^{77}$ Berkowicz, Sipurim..., s. 49.

78 Tamże, s. 60.

${ }^{79}$ Tamże, s. 55. 
[córce] o całym swoim życiu, pełnym cierpienia i nudy, dniach ubóstwa, koszmarnych, przepłakanych nocach"80. Rodzina jest hermetyczna, nie utrzymuje żadnych więzi społecznych. Rolnik, bibliotekarz i swatka pojawiają się tylko w kontekście pracy, którą wykonują.

Szifra zauważa, że życie rodziców uzależnione jest od uprawy i handlu tytułowymi „ogórkami”. Warzywa wypełniają je zarówno dosłownie, jak i w przenośni. Są one nie tylko głównym źródłem utrzymania rodziny, ale i sensem jej życia:

Czas zbioru ogórków [...] to hałaśliwe, dziwne i inne od pozostałych dni w roku, w których od wczesnego ranka aż do północy panował w domu niespokojny zgiełk, dziwne zamieszanie, szybciej płynąca w żyłach krew, bieganina, desperacki i rozpaczliwy krzyk ${ }^{81}$.

Warzywa zajmują niemal całą przestrzeń domu: „W jednym z kątów gniła sterta podłużnych i powykrzywianych ziemniaków, których białe korzenie wyrastały z ciemności i wystawały z niej jak robaki" ${ }^{82}$. Dni domowników wypełnia ciężka praca fizyczna w gospodarstwie, która tłumi ich rzeczywiste potrzeby i myśli:

Człowiek rodzi się, żeby wieść marne życie i męczyć się pod brzemieniem. Jest podobny bydlęciu, temu wołowi, który musi robić to, co mu każe ten, kto go bije, więc ciągnie jarzmo. [...] aż nadchodzi dzień, gdy upadamy twarzą na ziemię ${ }^{83}$.

W przeciwieństwie do śmiejących się i śpiewających podczas pracy gojek swoją pracę traktują jak niekończącą się mękę: „Zamyślony ojciec stoi obok stosu ogórków z laską w ręku. Ciężkie krople potu spływają mu po czole, jego brodata twarz jest posępna, smutna i wpatrzona w pustkę" ${ }^{84}$.

Jałowe i bezsensowne życie domowników przejawia się także w ich rutynowym podejściu do religii i obyczajów. Modlitwa, podobnie jak praca na roli, nie daje im satysfakcji. Talit i tefilin (filakterie) są dla nich symbolami pozbawionymi głębszego znaczenia, nie oddają im należytego szacunku: „Pod pachą trzymał pokrowiec na talit, a w ręce lampkę wódki i śledzia”, „chłopak poszedł w filakteriach przeganiać świnie z ogrodu" ${ }^{85}$.

\footnotetext{
${ }^{80}$ Tamże, s. 49.

81 Tamże.

82 Tamże, s. 50

83 Tamże, s. 56.

${ }^{84}$ Tamże, s. 58.

${ }^{85}$ Tamże, s. 61.
} 
Toksyczna atmosfera panująca w domu jest głównym źródłem cierpienia Szifry. Czuje się w nim obco i jako taka jest postrzegana przez rodzinę. Kiedy wszyscy pracują w ogrodzie, ona błąka się po domu bez celu. Brakuje jej możliwości, jakie niegdyś dawało jej miasto. Tęskni za jego pięknem i świeżością. Z dnia na dzień coraz dotkliwiej uświadamia sobie swój żałosny los i zmarnowaną młodość: „Nikt się [nią] nie interesuje, [jej] życie kończy się, lecz nikt tego nie zauważa. [...] kręci się po [domu], jakby była tam obca"s6.

Szifra wyglądem zaczyna przypominać pozostałych członków swojej rodziny. Jej cera przybiera zielony, niczym kolor ogórków odcień: „Patrzy na swoją szczupłą i zieloną twarz, długi nos, ponure oczy i na ukrytą w nich rozpacz" ${ }^{87}$. Jej letnie, białe stroje kontrastują ze starzejącą się twarzą i jesiennymi, deszczowymi dniami.

Na próżno przeciwstawiać się zarzutowi krytyka literatury hebrajskiej Avnera Holtzmana wobec naiwności i protekcjonalności Szifry. Analogicznie do męskich protagonistów ona także postrzega siebie jako osobę o ponadprzeciętnych zdolnościach i talentach, które jednak znikają w zderzeniu z rzeczywistością. Ucieczką od przytłaczającego ją otoczenia są marzenia i iluzje inspirowane powieściami. Szifra wyobraża sobie siebie jako bohaterkę jednego z rosyjskich romansów. Kopiuje styl bycia pięknych kobiet, o których względy zabiegają mężczyźni, a nawet toczą pojedynki. Wszystkie jej plany weryfikuje rzeczywistość, a marzenia rozwiewają się jedno po drugim. Jej marzenia to na przykład zaprowadzenie porządku w domu: „będzie zarządzała całym domem, ozdobi go ładnymi naczyniami, plecionymi firankami”, lub dołączenie do pracujących w ogrodzie: „Wyobraziła sobie całodniową pracę w polu, od rana do wieczora, razem z innymi dziewczętami ze wsi" ${ }^{88}$. Z powodu nieadekwatności stroju i braku nawyku pracy fizycznej zostaje jednak wyśmiana przez pracowników.

Jak słusznie zauważyła Ronit Guez, główne cele życia Szifry to małżeństwo, miłość, bycie kochaną i zauważaną ${ }^{89}$. W małżeństwie widzi możliwość ucieczki z domu i szansę na szczęście. Niemniej, marzenia te jedynie potęgują jej cierpienie. Bohaterka snuje naiwną wizję ślubu z bibliotekarzem. Mężczyzna z racji wykonywanego zawodu zdaje sie jedynym w miasteczku wartym jej uwagi. Ostatecznie dziewczyna uświadamia sobie, że swoją wyjątkową

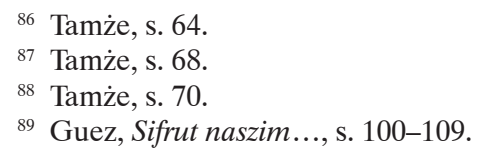


uprzejmością darzy on także inne czytelniczki, co pozbawia ją resztek chęci do życia: „Stoi między nimi zagubiona, nieszczęśliwa, niewidzialna, próbuje nawet śmiać się z nimi, ale wychodzi jej tylko mizerny uśmiech" "90.

Dodatkowym ciosem, a zarazem definitywnym odarciem jej ze złudzeń, jest zainicjonowane przez ojca swatanie. Na tym przykładzie widać wyraźny rozdźwięk między ideałem romantycznej miłości a tradycyjną koncepcją żydowskich standardów zawierania małżeństw. Celem ojca było przyporządkowanie Szifrze tradycyjnej roli wynikającej z płci. Wizja pustego życia u boku niekochanej osoby jest dla niej smutnym powieleniem losu jej rodziców. Sytuacja ta prowokuje u niej nawet myśli samobójcze: „wbijała twarz w poduszkę i błagała o śmierć" ${ }^{\prime 1}$. Porównywalnie ze wszystkimi bohaterami wykorzenionymi samobójstwo postrzega jako ucieczkę od nieuchronnego przeznaczenia. Brakuje jej jednak odwagi do popełnienia tego „nieodwracalnego czynu”: „Gdy Szifra dotarła już do mostu i kiedy wybiła jej ostatnia godzina [...] skoku do rzeki, ogarnął ją nagle ogromny niepokój i przerażenie ciemnością"92. Most zarówno w opowiadaniach Berkowicza (Ruchot Raot), jak i Berdyczewskiego (Me'ewer la-nahar) ma wymiar symboliczny. Jest „przejściem” na drugą stronę, do nieznanego świata. Uzupełnieniem ostatecznego upadku bohaterki jest finałowa scena w ogrodzie, kiedy siedzi nieruchomo i „grzeje się w słońcu niczym roślina" ${ }^{93}$. Należy ją rozumieć jako poddanie się przeznaczeniu, akceptację losu i rezygnację z dalszych prób jego polepszania. Metaforą losu Szifry jest „kiszony ogórek”, ponieważ okres od wiosny do jesieni przypomina proces sukcesywnego więdnięcia jej życia.

Nie ulega wątpliwości, że na losy bohaterki należy patrzeć przez pryzmat braku możliwości zdobycia wykształcenia na takim samym poziomie jak mężczyźni. Czytanie książek jest dla niej jedynym sposobem kształtowania i ustanawiania kobiecego światopoglądu, swojej tożsamości osobistej, klasowej i kulturowej. Mimo wysokich ambicji i możliwości intelektualnych

${ }^{90}$ Berkowicz, Sipurim ..., s. 75.

91 Tamże, s. 77. Przedstawienie wzorca kulturowego tradycyjnej rodziny żydowskiej jest przykładem kultury postfiguratywnej Margaret Mead zakładającej, że rodzice są nieocenionymi przodkami, a dzieci uczą się od nich określonych wzorców życiowych. Zachowanie niezgodne z tradycją może skutkować wykluczeniem z danej grupy. Margaret Mead, Kultura i tożsamość: studium dystansu międzypokoleniowego, tłum. Jacek Hołówka, Warszawa 2000, s. 117-125; Anne Lapidus-Lerner, Lost Childhood in East European Hebrew Literature, [w:] The Jewish Family: Metaphor and Memory, red. David Kraemer, New York 1989, s. 95-115.

${ }^{22}$ Berkowicz, Sipurim..., s. 78; Arnold van Gennep, Obrzędy przejścia, thum. Beata Biały, Warszawa 2006.

${ }^{93}$ Berkowicz, Sipurim..., s. 79. 
ówczesne kobiety żydowskie rzadko otrzymywały wsparcie ze strony rodziców i otoczenia. Dowodem na to są słowa ojca Szifry: „Teraz rozumiem, czyli edukacja... Kształcisz się... Schodzisz na manowce. Jaka jest [z tego] korzyść...?"94. Okoliczności, w jakich się znalazła, skutecznie uniemożliwiają jej manifestowanie własnego indywidualizmu. Wszelkie próby wyjścia poza utarty schemat życia w sztetlu spotykają się z niezrozumieniem lub kpiną. Jej życiowy cel został jasno sformułowany: miłość i szczęście. Jednakże namiastkę tych uczuć odnajduje jedynie w romansach. Ocenianie jej postawy według tych samych kryteriów co męskich przedstawicieli inteligencji jest błędne. Przedstawiciele obojga płci nie mieli równych szans w kwestii edukacji. Przeświadczenie Szifry o byciu kimś ponadprzeciętnym wynikało z zaznania nowoczesnego świata, do którego większość żydowskich dziewcząt nie miała prawa wstępu.

\section{Zakończenie}

Jak wynika z powyższej analizy utworów Karet oraz Melafefonim Berkowicza, przyczyny wykorzenienia u obu bohaterek są odmienne. Odwołując się do omówionych na początku artykułu kategorii wykorzenionych zaproponowanych przez Halkina, należy stwierdzić, że Dwora reprezentuje drugą z nich - uwięzionych pomiędzy dwoma światami. Silne przywiązanie do tradycji uniemożliwiło jej przystosowanie się do nowych, świeckich porządków. Różnice kulturowe nie pozwoliły na urzeczywistnienie pożądanej zmiany. Powrót do sztetla jest niemożliwy, ponieważ ten już nie istnieje. Jej życie w Ameryce okazało się kolejnym „wygnaniem”. Losy Dwory w szerszym ujęciu uwypuklają bezdomność narodu żydowskiego, a tym samym - ostatecznie przekreślają jego marzenia o niepodległości. Biorąc natomiast pod uwagę klasyfikację Gowrin, Dworę możemy przyporządkować do pierwszej grupy bohaterów Berkowicza. W jej przypadku nie mamy do czynienia z jawnym buntem, toczy ona bowiem wewnętrzną walkę. Nie potrafi sprzeciwić się domowemu porządkowi i wybiera cierpienie w samotności. Kobieta jest więziona i torturowana przez własne słabości, co ostatecznie doprowadza ją do załamania psychicznego.

Szifra natomiast należy do pierwszej kategorii wykorzenionych Halkina wiążącej się ze zmianą statusu społecznego i z problemem ponownego przystosowania się. Wyjazd do miasta wyraźnie poprawił jej dobrobyt. Widzimy

94 Tamże, s. 65. 
przepaść między biedą, w której się wychowała, a dobrymi warunkami, w jakich żyła w mieście. Powrót do domu odebrał jej poczucie komfortu ekonomicznego i uniemożliwił dalszy rozwój osobisty. W podziale bohaterów Berkowicza proponowanym przez Gowrin Szifra reprezentuje tych, którzy po powrocie z długoletniej absencji czują się w domu rodzinnym obco i jako obcy są tam postrzegani. Była dumna z postępów, jakie poczyniła, mieszkając w Warszawie. Nie chciała ponownie podporządkować się regułom życia w domu i miasteczku. Jej losy udowadniają, że wyobcowanym można się czuć także w dobrze znanym nam środowisku. Mimo wielu różnic między bohaterkami ich życiowe tragedie wypływają z tego samego źródła, którym jest niemożność pogodzenia dwóch, odmiennych bytów. W szerszej perspektywie utwory te przedstawiają historie kobiet żydowskich, których życiorysy były uzależnione od skostniałych zasad społeczności.

Przedstawienie wykorzenionych bohaterek $w$ roli protagonistek należy uznać za rewolucyjne. Można wnioskować, że główną intencją takich pisarzy jak Berdyczewski czy Berkowicz była próba znalezienia języka dla kobiecych doświadczeń, upomnienia się o widzialność kobiet i udzielenia im głosu. Za pośrednictwem kreowanych przez nich portretów wskazywali na społeczne wykluczenie kobiet żydowskich. $\mathrm{Z}$ analizy opowiadań wynika, że kobiece doświadczenie wykorzenienia nierzadko przybierało skrajniejszą formę, ponieważ dotykało kobiet w szerszym wymiarze, na wielu płaszczyznach życia. Ich zawiłe losy nie zawsze były wynikiem samodzielnie podjętych decyzji, lecz konsekwencją odgórnie ustalonych reguł społecznych. Włączenie kobiecej postaci do grona bohaterów wykorzenionych zachęciło kolejne pokolenia hebrajskich twórców do zajęcia się tym tematem, a co najważniejsze - uprawomocniło kobiece pisarstwo i umożliwiło mu wejście w przestrzeń publiczną. Pisarze ci zaznaczyli obecność kobiet, nawet jeśli była ona jeszcze śladowa i we wstępnej fazie konceptualizacji. Warto jednak się zastanowić, w jakim stopniu kreacja kobiety wykorzenionej widziana oczami mężczyzn była kompatybilna z jej osobistym doświadczeniem. Mimo wymienionych powyżej pozytywnych aspektów kreacja literacka nie zawsze jest prawdziwym wizerunkiem pierwowzoru. Kobiety te opisywano jako będące całkowicie pod kontrolą mężczyzn lub jako niezależne i starające się wyjść poza ograniczenia czy też jako takie osoby, które balansowały na ich styku. Istniało ryzyko tendencyjnego podejścia do ich historii, spłycania, przemilczania, tworzenia alternatywnej wizji, a nawet przekłamywania poszczególnych aspektów życia kobiet. Zagadnienie to jest jednak tematem na osobną rozprawę. 


\section{Bibliografia}

\section{1. Źródła opublikowane}

Berkowicz Icchak D., Sipurim, Kraków 1910.

Berkowicz Icchak D., Sipurim niwcharim, Tel Awiw 1966.

\section{Opracowania}

Abramowska Janina, Topos i niektóre miejsca wspólne badań literackich, „Pamiętnik Literacki" 73 (1982), nr 1-2.

Bar-Josef Chamutal, Magaim szel dekadens, Bialik, Berdyczewski, Brener, Be'er Szewa 1997.

Bar-Josef Chamutal, Mawo le-sifrut ha-dekadens be-Ejropa, Tel Awiw 1994.

Bukała Marta Z., Andronice Marii Komornickiej - między kreacja femme fatale a gnostycka transgresja, „Annales UMCS. Sectio FF, Philologiae” (2014), nr 32.

Cohen Tova, Portrait of the Maskilah as a Young Woman, „Nashim” (2008), nr 15.

Fajtelson Menachem M., Ha-isza ha-misztochreret be-sifrutenu, [w:] tenże, Ktawim. Sefer riszon, Jeruszalajim 1914.

Gowrin Nurit, Tliszut we-hitchadszut: Ha-siporet ha-iwrit bereszit ha-mea ha-esrim ba-gola u-we-Erec-Israel, Tel Awiw 1985.

Halkin Szimon, Mawo la-siporet ha-iwrit. Reszimot lefi harcaotaw szel Sz. Halkin, Jeruszalajim 1959.

Halkin Szimon, Modern Hebrew Literature. From the Enlightenment to the Birth of the State of Israel: Trends and Values, New York 1970.

Holtz Avraham, Isaac Dov Berkowitz: Voice of the Uprooted, London 1973.

Holtzman Avner, Anatomia szel tliszut: Al sipuro szel I. D. Berkowicz Melafefonim, [w:] Ahawot Cijon. Panim ba-sifrut ha-iwrit ha-chadasza, red. Avner Holtzman, Jeruszalajim 2006.

Jaworska Agata, Na rozdrożu: Wizerunek bohatera wykorzenionego (talusz) na przykładzie prozy J. Ch. Brennera oraz M. J. Berdyczewskiego. Część I: Josef Chaim Brenner, [w:] Języki i cywilizacje. Młodzi badacze na stulecie Orientalistyki w Krakowie, red. Karolina W. Olszowska, Joanna Świt, Marcin Gajec, Kraków 2020.

Keszet Jeszurun, Be-dor ole: Masot al I. D. Berkowicz, Tel Awiw 1950.

Kłosińska Krystyna, Kobieta autorka: teoria literatury, krytyka, interpretacja, „Teksty Drugie" (1995), nr 3-4.

Kurzweil Baruch, Zikaron la-riszonim, „Katharsis” (2008), nr 10.

Lapidus-Lerner Anne, Lost Childhood in East European Hebrew Literature, [w:] The Jewish Family: Metaphor and Memory, red. David Kraemer, New York 1989.

Lisek Joanna, Kol isze - głos kobiet w poezji jidysz (od XVI w. do 1939 r.), Sejny 2018.

Mead Margaret, Kultura i tożsamość: studium dystansu międzypokoleniowego, tłum. Jacek Hołówka, Warszawa 2000.

Miron Dan, Bejn Icchak Dow Berkowicz li-wnej doro: Sziszim szana le-pirsum sipuro ha-riszon, [w:] tenże, Kiwun Orot, Tel Awiw 1979.

Miron Dan, Why Was There No Women's Poetry in Hebrew Before 1920?, [w:] Gender and Text in Modern Hebrew and Yiddish Literature, red. Naomi B. Sokoloff, Anne Lapidus-Lerner, Anita Norich, New York 1992. 
Mosse George L., Nationalism and Sexuality: Respectability and Abnormal Sexuality in Modern Europe, New York 1984.

Oxford English-Hebrew and Hebrew-English Dictionary, red. Ya'acov Levy, Jerusalem 1995.

Parush Iris, Reading Jewish Women: Marginality and Modernization in NineteenthCentury Eastern European Jewish Society, Waltham 2004.

Shait Heddy, The Female Rootless Character in Hebrew Prose: Initial Attempts at Shaping Her Image, „Women in Judaism” 10 (2013), nr 1.

Shaked Gershon, Modern Hebrew Fiction, tłum. Yael Lotan, red. Emily Miller Budick, Bloomington 2000.

Shenkar Yael, Ha-tluszot min ha-sifrut-Al mikuman szel naszim be-sifrut ha-tluszim, [w:] Rega szel huledet. Mechkarim be-sifrut iwrit u-we-sifrut jidisz, red. Hannan Hever, Jeruszalajim 2007.

Szwabowicz Magda S., Hebrajskie życie literackie w międzywojennej Polsce, Warszawa 2019.

Van Gennep Arnold, Obrzędy przejścia, tłum. Beata Biały, Warszawa 2006.

Werses Shmuel, Portrait of the Maskil as a Young Man, [w:] New Perspectives of the Haskalah, red. Shmuel Feiner, David Sorkin, London 2001.

Zeidler-Janiszewska Anna, Dryfujący flâneur, czyli o sytuacjonistycznej transformacji doświadczenia miejskiej przestrzeni, [w:] Przestrzeń, filozofia i architektura. Osiem rozmów o poznawaniu, produkowaniu i konsumowaniu przestrzeni, red. Ewa Rewers, Poznań 1999.

\section{3. Źródła internetowe}

Bartal Israel, Haskalah Literature: Portrayal of Women, [w:] The Jewish Women's Archive, https:/jwa.org/encyclopedia/article/haskalah-literature-portrayal-ofwomen [dostęp: 30 czerwca 2021].

Encyclopaedia Judaica, red. Fred Skolnik, Michael Berenbaum, wyd. 2, Detroit 2007, http://www.jevzajcg.me/enciklopedia/Encyclopaedia\%20Judaica,\%20 v.\%2008\%20(Gos-Hep).pdf [dostęp: 19 listopada 2020].

Guez Ronit, Sifrut naszim we-sifrut gwarim: masa u-matan al ha-naratiw ha-leumi, Be'er Szewa 2011, http://aranne5.bgu.ac.il/others/GuezRonit.pdf [dostęp: 19 listopada 2020].

Jastrow Marcus, A Dictionary of the Targumim, the Talmud Babli and Yerushalmi, and the Midrashic Literature, https://www.tyndalearchive.com/TABS/Jastrow//? fbclid=IwAR2j4yjrWKrD2v5Ie_u04QLIAs19D9z3pYPSnHiUPS6c7VoLKsfNCmEnMbU [dostęp: 24 czerwca 2021].

Mishnah, [w:] The Sefaria Library, https://www.sefaria.org/texts/Mishnah [dostęp: 4 lipca 2021].

Agata Jaworska

Uniwersytet Jagielloński

Wydział Filologiczny, Katedra Arabistyki agata.jaworska@doctoral.uj.edu.pl 
